\title{
AHP APPLICATION IN BANKING: UNFOLDING UTILITY IN A SITUATION OF FINANCIAL CRISIS
}

\author{
Shashi Bhattarai ${ }^{1}$ \\ Development Dynamics Pvt. Ltd. \\ GPO Box 2897, Kathmandu, Nepal \\ E-mail: shashi@icon.com.np \\ Shivjee Roy Yadav \\ Nepal Industrial Development Corporation, Kathmandu, Nepal \\ E-mail: shivjeer@yahoo.com
}

\begin{abstract}
The paper reviews application of Analytic Hierarchy Process (AHP) in the finance sector with specific reference to banking. The paper also describes feedback from bankers' community in Nepal on utility of AHP as a decision support tool. We have put effort to explore and demonstrate utility of AHP application in banking in the situation of global financial crisis.

Despite of widespread and consistent application of AHP in business and industry, its application in banking sector is commonly initiated in the late nineties. Application of AHP in Southeast Asian countries and cases appeared in literature are observed after the regional financial crisis in mid nineties. AHP has been seen as a high potential decision support tool in banking sector in the days to come. We have also presented a bibliography of AHP application in banking in the paper.
\end{abstract}

Keywords: AHP, Banking, Banking decision-making, financial crisis

\section{Introduction}

As Analytic Hierarchy Process (AHP) is the widely used decision support tool in business and industry, we have focused on financial sector of service industry in this paper. Banks and financial institutions are key decision makers for controlling application of finance, its disbursement and availability in the market. The global financial crisis and banking system are part and parcel of the current economic situation. It has been felt that a review and application of AHP/ANP (Analytic Network Process) in the banking industry would be a timely effort. The review is combined with the application of AHP/ANP in banking and financial risk management for the service business sector.

The review of AHP/ANP application in banking is based on earlier application reviews including ISAHP papers starting from 2001. Isolated application papers are also reviewed mostly at abstract level. A bibliography of AHP applications made in banking and financial sector identified through internet searches is presented in the reference section of the paper.

AHP application in banking sector is growing most recently, it is being combined with conventional bank evaluation or credit rating tools. With the global financial crisis, utility of AHP is being perceived higher in banking application. The use of AHP as a decision support tool is appreciated by banking communities in Nepal, when the utilities are informed to them.

\footnotetext{
${ }^{1}$ Corresponding author
} 
Real life application of AHP/ANP in banking has a great potential. There is more to done by commercial system producers or software vendors than by the academic communities to promote the wide-spread use of AHP/ANP based decision support system in banking communities' world wide.

\subsection{Review of Application AHP in Banking}

There is very limited literature available on the application or utility of AHP/ANP in the banking sector. Banking decision and application cases of decision support tools in banks are confidential information. However, overviews of AHP application literatures are revisited to focus on banking. Some of specific applications in banking are discussed and bibliography of AHP application in banking is presented.

Multiple criteria decision making (MCDM) combined with finance and categorized bibliographic study (Steuer and Na, 2003) had excellently presented distribution of application of AHP among other MCDM tools. We have focused the bibliographic study on AHP and banking. The 265 papers referred on the study had identified only 18 papers on application of AHP in finance, among the 18 papers, only 8 cases are related to application in banking. Chronologically, most of the AHP applications in banking are seen after 1990. The AHP application identified by (Steuer and $\mathrm{Na}$, 2003) includes forecasting foreign exchange rates (Ulengin and Ulengin, 1994), business strategy formulation for a financial institution (bank) in a developing country (Vargas and Roura-Agusti, 1989), selecting priority industry for investment (Rashid and Tabucanon, 1991), selecting a financial instrument for foreign investment (Meziani and Rezvani, 1990), international investment risk analysis (Jensen, 1987), evaluation of clients in financial houses (Jablonsky, 1993), prediction of corporate bankruptcy (Hogan et. al, 2000) and bank strategic planning for merger and acquisition (Arbel and Orger, 1990).

The other recent AHP application review (Vaidya and Kumar, 2006) cited 150 AHP application papers mainly after 1990 (132 papers out of 150), only two applications are classified as application in banking (Arbel and Orger, 1990) and (Ehie, et al., 1990). The application review includes earlier application surveys (Zahedi, 1986), (Vargas, 1990) and (Steuer and Na, 2003). The two AHP applications categorized as application in banking include work on bank strategic planning focusing on merger and acquisitions process (Arbel and Orger, 1990) and setting up development goals in low-income developing countries (Ehie, et al., 1990).

Observing the previous ISAHP papers, since 2001, we find that one or two papers on each symposium relating to banking or financial crisis, eg. (Azis, 2007), (Kusumaningtuti et al., 2007), (Michnik and Lo, 2005), (Hunjak and Cingula, 2005), (Azis, 2003), (Hunjak and Jakovèeviæ, 2001). Among the work presented in the ISAHP meetings, enhancement of financial risk assessment (Michnik and Lo, 2005), securities portfolio modeling for emerging markets (Hunjak and Cingula, 2005), model for bank performance evaluation and rating highlighting CAMEL rating (Hunjak and Jakovèeviæ, 2001); and legal role on banking crisis resolution in Indonesia (Kusumaningtuti et al., 2007) are relevant and pioneering work on application of AHP/ANP in banking and unfolding utility in a situation of financial crisis.

Some of the specific cases of AHP application in banking that have been identified are (Frei and Harker, 1998), (Macerinskiene et al., 2004), (Domański and Kondrasiuk, 2005), (Korhonen and Raimo, 2004), (Bernè et al., 2006) and (Lee and Jao-Hong, 2008) which are discussed further.

Specific work on AHP application in banking with collection of application examples (simple and ready to use kind of problems for real life banking decision problems) are rarely seen in literature, however the work by (Domański and Kondrasiuk, 2005) is the one among few identified. The various areas of decision problem where application of AHP is demonstrated are: establishing bank deposit interest rates, 
price assessment of bank deposits, base loan rate determination, bank marketing strategy decisions, merger related decisions, bank head office location decision, bank departments evaluation, bank IT system selection decisions, bank human resources decisions which include board members and key employee selection as well. (Domański and Kondrasiuk, 2005).

Utilization of AHP for measuring aggregate process performance and a methodology taking empirical example of retail banking industry is presented in (Frei and Harker, 1998). Review of multi criteria framework of financial decisions of bank loan portfolio management as decision support is presented in (Macerinskiene et al., 2004). Bridging the gap between decision-making disciplines of financial economics and recommendation on need of AHP kind of multi criteria tool for complex modern bank loan portfolio management decision-making is emphasized (Macerinskiene et al., 2004).

While assessing the most preferred alliances between banks and insurance companies (Korhonen and Raimo, 2004) re-insisted that application of AHP is much less frequent in financial problems, which can be observed on the work by (Steuer and $\mathrm{Na}, 2003$ ) as well. Expert panel assisted by the AHP was a successful approach in searching most preferred structure between banks and insurance companies (Korhonen and Raimo, 2004).

Global competitiveness of local companies, with specific reference to banking industry in Thailand is accessed on work by (Sirinaovakul, 2002). Survival of local banks in global competitive environment and factors to enhance the global competitiveness of four Thai Banks was identified and the result was in line with those of international credit rating agencies, including Standard \& Poors and Moody's Investors Service (Sirinaovakul, 2002).

AHP in addition to other statistical tools were utilized while developing multi criteria credit rating (MCCR) process based on Basel II guidelines (Bernè et al., 2006) which expressed the following opening statement:

"Credit risk affects virtually every financial contract. Therefore the measurement, pricing and management of credit risk has received much attention from practitioners who have a strong interest in accurately pricing and managing this kind of risk and from financial economists who have much to learn from the way such risk is priced in the market, and from bank authorities who need to design minimum capital requirements that correctly reflect the credit risk of banks' loan portfolios. Following the work of the Basel Committee on Banking Supervision to reform the capital adequacy framework by introducing risk sensitive capital requirements, significant attention has been devoted to the subject of credit risk measurement by the international regulatory, academic and banking communities".

The work by (Bernè et al., 2006) is an integrated methodology combining conventional credit rating with numerical methods and AHP to assess distress of industrial companies according to Basel II guidelines.

Critical factors in selecting high yield bonds (HYBs) using fuzzy AHP (Lee and Jao-Hong, 2008) is evaluated. As the returns and risks of HYB lie between the stocks and treasury bonds, the critical evaluation criteria related to HYB selection identified and included other two parameters in addition to default rate indicator.

Interestingly, (Fan and Cheng, 2009) utilized AHP along with TOPSIS to evaluate curriculum in Department of Risk Management and Insurance at Universities. The study (Fan and Cheng, 2009) triggered with the financial liberalization and deregulation process in Taiwan since 2000, needing more competitive graduates in banks and financial institutions. The study recommended a decision model which will help human resources managers in bank and insurance companies in hiring more qualified graduates for their companies. 
We could observe that the application of AHP/ANP in finance emerged mostly after 1990. Specific applications of AHP/ANP in banking, like credit rating, risk assessments in banking and investment are more apparent after 2000. Conventional credit rating and bank evaluation tools like CAMEL, Basel II are seen combined with AHP/ANP most recently, and were found to give more insights on risk assessments when such combined applications are made.

Banks are important players in the financial market, their role mainly is to provide credit services. Banks are licensed by the governments to operate their business and are regulated by respective governments. Financial crisis triggered from sub-prime lending from retail banking sector in the US vis-à-vis review of application of AHP/ANP in banking sector is now a very important research and practical application area. The prime or sub-prime lending is demarcated by a certain credit score, in the US sub-prime loans are classified as those where the borrower has a FICO (Fair Isaac Credit Organization) score below 640, generated out of five major criteria (punctuality of payment in the past, amount of debt, length of credit history, type of credit used, resent search of credit and / or amount of credit obtained recently) with assigned weights to each criteria (Wikipedia, 2009a), (Wikipedia, 2009b). Credit rating score and incorporating risk into strategic lending decisions is considered as a complex multiple criteria decision making problem.

The leading banking computer software solution (Finacle) provider (Infosis) says "regulatory mandates, the increasing complexities and diversification of financial services firms, growing margin pressure, and stinging corporate scandal are compelling to adopt a dynamitic, process oriented discipline of enterprise risk management (ERM)" (Fernandes, 2005). ERM needs to be seen holistic with risks across instruments, portfolio, business line and geography. Aggregating these in a holistic way is possible with AHP/ANP kind of multi criteria analysis solutions. "ERM is incomplete without right combination of risk technology process and a risk methodology within a banking organization" further specified (Fernandes, 2005); this remark is crucial in unfolding the utility of AHP/ANP application in the banking industry.

\subsection{Decision Making and Nepalese Banking Industry}

Utilization of advance decision support system in banking is new to global banking system. Nepalese context of banking business is on very early stage as the service is still to reach common household. Nepalese bankers with access to corporate houses and white color job holders perceived very little to do with advanced decision support systems. The banking industry in Nepal is still in search of, and dependent on information, rather than to look for tool to integrate the information to get in-depth knowledge to support for making decision.

\subsection{General Background}

Nepal is a small economy country and has access to limited financial services to establish businesses, industries and individuals. Only $26 \%$ Nepalese households have bank accounts (World Bank, 2007). Utilization of computerized banking system, computerized networking among banks, generation of centralized management information system (MIS) and generation of some specific information for executives (executive information system, EIS) and central bank regulatory information are the priority areas in Nepal. Decision making in banking industry, even in the advanced and well doing commercial banks in Nepal is based on the human judgment with the support of isolated information generated by banking computer / MIS system. In the remittance based Nepalese banking economy, impact of global financial crisis is delayed, yet major implication is not widespread, however banks and financial institutions are more cautious and making their decisions carefully. However, several cases of central bank intervention on management and operation have appeared in the last five years. 
Responses from leading bankers on the awareness of decision support systems, growing complexities on decision making in banking, adequacy in making decisions with existing MIS/EIS, assessment of needs in terms of holistic decision making, getting insight into decision problems, maintaining institutional memory in crucial decisions, evaluation of past decisions and risk management as part of decision making are gathered and discussed in the following paragraph.

\subsection{Feedback from Nepalese Bankers' Community}

Nepalese banking industry, in general, are somehow aware with the availability of decision support systems, and recognize that information is necessary, but not sufficient in making decisions. The banking decision makers depend on the existing banking system generated MIS and human brain. The banking communities are convinced of the growing complexities in making crucial banking decisions coupled with the global financial crisis. In a recent round table discussion of bankers, most of the bankers were giving focus on availability and reliability of indicators / information, however, it was also pointed out that getting information is only the first step, but using available information for making decision is a more important step, pointing out the US banking system, where the information infrastructure is in maturity.

Perception on the need of decision support, AHP kind in banking with reference to the following identified utility is found positive.

1. ability of integrated / holistic decision analysis, putting subjective and objective information on the single framework for decision analysis

2. getting insight to critical decision problem, to look at 'what if' scenario, sensitivity analysis of decision problem and to get feedback on strategy formulation for risk management

3. decision analysis from corporate governance prospective, like transparency on decisions, consensus building and addressing to shareholders' aspirations

4. creation of corporate memory on critical decisions, learning from past decisions, independent of executives on lead in institutions, focusing on organizations rather than individuals.

The utility of AHP/ANP kind of decision support system on the above fronts are appreciated and expressed the need by the Nepalese bankers. In the current practice, decisions are made taking care of indicators and information (subjective as well as objective), tradeoffs and judgments are supported by human brain.

Awareness on decision support systems are there and convinced that the decision making in banking business is becoming complex day by day coupled with competition, global financial crisis, stringent regulations and increased shareholders' aspirations. Local bankers are also convinced that MIS/EIS are necessary but not sufficient for making decisions in banking business. It is also reported that very few banks in Nepal initiated risk management as a part of the decision making process but more needs to be done.

\subsection{Conclusion}

It is observed that the application of AHP/ANP specifically in banking and financing sector is less than three percent of the total application, it has became more intense academic research only after 2000. Still, AHP/ANP based decision support is quite new to real life bankers. Following the global financial crisis, more research and application of AHP/ANP in banking sector triggered specially the need of integration with the traditional credit information system. It is also observed that after Asian financial crisis, instances of research and application of AHP/ANP have grown in countries like Thailand, Indonesia, 
Vietnam and Taiwan. China is already ahead in AHP/ANP applications, although specific application in banking is not reported in this paper. The recent AHP application review is seen from India.

There is growing need of AHP/ANP based decision support systems in banking sector. The utilities which could offer AHP/ANP kind of decision support systems are appreciated by the banking professionals. Making real life application of AHP/ANP has potential and more needs to be done by commercial system producers or software vendors than by the academic communities on gaining AHP/ANP based decision support system widespread application by the banking communities' world wide.

\section{REFERENCES}

Arbel, A. \& Orger, Y.E. (1990). An application of AHP to bank strategic planning: The merger and acquisitions process, European Journal of Operational Research 48 (1) 27-37.

Angels, D.I. \& Lee, C.Y. (1996). Strategic investment analysis using activity based costing concepts and analytic hierarchy process techniques, International Journal of Production Research 34 (5) 1331-1345.

Apostolou, B.A. (1989). An investigation of internal auditor judgment on the importance of indicators of potential financial fraud: an analytic hierarchy process approach, DAI-A 49/12, 3779.

Azis, Iwan J. (2007). Exploring important elements of regional financial arrangement by using the analytic network process, Proceedings of ISAHP 2007 (Tutorial), Chile.

Azis, Iwan J. (2003). Complex decision in the establishment of Asian regional financial arrangement, Proceedings of ISAHP 2003, Bali, Indonesia.

Bagchi, P. \& Rao R.P., (1992). Decision making in mergers: An application of the analytic hierarchy process, Managerial and Decision Economics, Vol., 13, No. 2, pp. 91-99.

Bahmani, N., Yamoah, D., Basseer P. \& Rezvani, F. (1987). Using the analytical hierarchy process to select investment in a heterogeneous environment, Mathematical Modelling 8, 157-162.

Bernè, F., Mattia C., Maurizio F., Daria M., \& Pediroda V. (2006). Multi Criteria Credit Rating (MCCR): A Credit Rating Assignment Process for Italian Enterprises According to Basel II, Proceedings of MCDM 2006, June 19-23, 2006, Chania, Greece.

Domański Cz. \& Kondrasiuk J. (2005). Analytic Hierarchy Process - Applications in Banking, in Baier D., Wernecke K.D. (ed.): Innovations in Classification, Data Science, and Information Systems, Springer.

Ehie, I.C., Benjamin C.O., Y. Omurtag \& L. Clarke (1990). Prioritizing development goals in low-income developing countries, Omega 18 (2) 185-194.

Fan, Chiang Ku \& Cheng, Shu Wen (2009). Using Analytic Hierarchy Process Method and Technique for Order Preference by Similarity to Ideal Solution to Evaluate Curriculum in Department of Risk Management and Insurance, Journal of Social Sciences, 19 (1): 1-8.

Ferandes, Merwin (2005). A Risk-free Enterprise, Finacle Connect, Quarterly Journal of Finacle Infosis, Issue 4. 
Frei, Frances X. \& Harker, Patrick T. (1998). Measuring Aggregate Process Performance Using AHP, Working Paper, Wharton Financial Institutions Center, The Wharton School, University of Pennsylvania, Philadelphia, PA 98-07.

Fong, C.M., Ho, C.T. \& Nguyen, H.L. (2007). Using AHP in decision analysis - the case of Vietnam state securities commission, Proceedings of IEEE International Conference, ISBN 978-1-4244-1529-1, Singapore, 144-148.

Hogan, K.M., G.T. Olson, \& H.F. Rahmlow (2000). A Model for the Prediction of Corporate Bankruptcy Using the Analytic Hierarchy Process. In K. D. Lawrence, G. R. Reeves, \& R. K. Klimberg (eds.), MultiCriteria Applications, JAI/Elsevier, Amsterdam, pp. 85-102.

Hunjak, Tihomir \& Jakovèeviæ, D. (2001). AHP based model for bank performance evaluation and rating, Proceeding of ISAHP 2001, Berne, Switzerland.

Hunjak, Tihomir \& Cingula, Marijan (2005). The securities portfolio modelling for emerging markets, Proceedings of ISAHP 2005, Hawaii.

Jain, B.A. \& Nag, B.N. (1996). A decision support model for investment decision in new ventures, European Journal of Operational Research 90 (3) 473-486.

Jablonsky, J. (1993). Multicriteria Evaluation of Clients in Financial Houses, Central European Journal for Operations Research and Economics, Vol. 2, No. 3, pp. 257-264.

Javalgi, R.G., Armacost R.L. \& Hosseini J.C. (1989). Using the Analytic Hierarchy Process for Bank Management: Analysis of Consumer Bank Selection Decisions, Journal of Business Research 19/1, 3349.

Jensen, R.E. (1987). International Investment Risk Analysis: Extensions for Multinational Corporation Capital Budgeting Models, Mathematical Modelling, Vol. 9, Nos. 3-5, pp. 265-284.

Johnson, R.A., Srinivasan V. \& P.J. Bolster (1990). Sovereign Debt Ratings: A Judgmental Model Based on the Analytic Hierarchy Process, Journal of International Business Studies 21/1, 95-117.

Korhonen, Pekka \& Raimo, V. (2004). Finding the Most Preferred Alliance Structure between Banks and Insurance Companies, Helsinki School of Economics, Working Papers, W-386.

Kusumaningtuti, S.S., Abdullah, P., \& Yumanita, D. (2007). Legal role on banking crisis resolution in Indonesia: An Analytic Network Process approach, Proceedings of ISAHP 2007, Chile.

Lee, Chen-Yu \& Cheng, Jao-Hong (2008). A fuzzy AHP application on evaluation of high-yield bond investment, WSEAS Transaction on Information Science and Applications, 5 (6) 1044-1056.

Macerinskiene, I., Ivaskeviciute, L. \& Babarskas, J. (2004). Multiple Criteria in Bank Loan Portfolio Management, Ekonomika 67, ISSN 1392-1258.

Meziani, A.S. \& F. Rezvani (1990). Using the Analytic Hierarchy Process to Select a Financial Instrument for a Foreign Investment, Mathematical and Computer Modelling, Vol. 13, No. 7, pp. 77-82.

Michnik, Jerzy \& Lo, Mei-Chen (2005). Enhancement of financial risk management with the aid of analytic hierarchy process, Proceedings of ISAHP 2005, Hawaii. 
Nezhad, H.G. (1988). Risk Assessment for International Investment, Reprints of the International Symposium on The Analytic Hierarchy Process, Tianjin University, Tianjin, China, 371-380.

Rashid, M. \& M.T. Tabucanon (1991). An Integrated Multi-Criteria Approach for Selecting Priority Industries for Investment Promotion, Information and Management Sciences, Vol. 2, No. 2, pp. 73-90.

Sauber, M.H., Sanchez P. \& V.M.R. Tummala (1991). Launching New Products for LDCs: The AHP Approach, Journal of Global Business 2/2, 31-37.

Simkin, M.G., Bagranoff, N.A., \& Crawford, P.J. (1990). Using A Decision Support System to Manage Exchange Rate Risk, Oklahoma Business Bulletin 58/3, 32-35.

Sirinaovakul, B. (2002). Analytic hierarchy process model for global competitiveness of local companies a case for Thai banking business, IEEE International, IEMC '02, Vol 2, 242-847.

Srinivasan, V. \& Bolster, P.J. (1990). An Industrial Bond Rating Model Based on the Analytic Hierarchy Process, European Journal of Operational Research, 48/1, 105-119.

Srinivasan, V. \& Kim Y.H., (1989). Financial Applications of the Analytic Hierarchy Process, Proceedings of the International Conference on Multiple Criteria Decision Making: Applications in Industry and Service, Asian Institute of Technology, Bangkok, 795-832.

Srinivasan, V. \& Kim, Y.H., (1987). Financial Theory, Financial Strategy and the Analytic Hierarchy Process", Working paper, Northeastern University.

Srinivasan, V. (1986). Designing a Decision support System for Working Capital Management, DAI-A 47/01, 265.

Srinivasan, V., Kim, Y.H. \& R.A. Eisenbeis (1987). Credit Granting: A Comparative Analysis of Classification, Journal of Finance 42/3, 665-683.

Steuer, R.E. \& Na, Paul (2003). Multiple criteria decision making combined with finance: A categorized bibliographic study, European Journal of Operational Research 150 (3) 496-515.

Stout, D.E., Liberatore M.J. \& Monahan, T.F. (1991). Decision Support Software for Capital Budgeting, Management Accounting 73/1, 50-53.

Taziani, T.R., Sanci M., Jajanshahloo, G. R., Jablonsky J. \& Mosaffari, M. R. (2009). Ranking Bank Branches with Interval Data by IAHP, Int. Journal of Math. Analysis, 3/20, 971-983.

Tummala, V.M.R., Smith J.R. \& Uppuluri V.R.R., (1993). Evaluating Commercial Credit Decisions by Analytic Hierarchy Process, ASCI Journal of Management 12/1-2, 48-56.

Ulengin, F. \& Ulengin, B. (1994). Forecasting foreign exchange rates: A comparative evaluation of AHP, Omega 22 (5) 505-519.

Vaidya, O.S. \& Kumar, S. (2006). Analytic Hierarchy Process: Overview of Applications. European Journal of Operational research, 169(1), 1-29. 
Vargas, L., (1990). An overview of analytic hierarchy process: Its applications, European Journal of Operational Research 48 (1) 2-8.

Vargas, L. \& Roura-Agusti J.B. (1989). Business Strategy Formulation for a Financial Institution in a Developing Country, in: Golden, B.L. Wasil, E.A. \& Harker, P.T. (eds.), Applications of the Analytic Hierarchy Process, Springer-Verlag, New York, 251-265.

Wikipedia (2009a) http://en.wikipedia.org/wiki/Subprime (Accessed on 25 May 2009)

Wikipedia (2009b) http://en.wikipedia.org/wiki/FICO_score\#FICO_score (Accessed on 25 May 2009)

World Bank (2007). Access of Financial services in Nepal, The World Bank, Finance and Private Sector Development Unit, South Asia Region.

Zahedi, F., (1986). The Analytic hierarchy process: A survey of methods and its applications, Interfaces 16 (4) 96-108. 